\title{
Effect of Organizational Justice, Perceived Organizational Support and Employee Engagement to Employee Organizational Citizenship Behavior of Regional Secretariat of West Sumatra Province
}

\author{
Ivani $^{1}$ Bustari Muchtar ${ }^{2}$, Rosyeni Rasyid ${ }^{3}$ \\ ${ }^{1}$ Universitas Negeri Padang, Padang and Indonesia, $\square$ ivani@gmail.com \\ ${ }^{2}$ Universitas Negeri Padang, Padang and Indonesia, $\square$ bustarimuchtar@gmail.com \\ ${ }^{3}$ Universitas Negeri Padang, Padang and Indonesia, $\square$ rosyenirasyid@yahoo.co.id
}

\begin{abstract}
The purpose of this study is to analyze the Influence of Organizational Justice, Perceived Organizational Support and Employee Engagement to Employee Organizational Citizenship Behavior Regional Secretariat of West Sumatra Province. This study used 464 respondents as the sample. The data analysis technique of this study is path analysis. The results showed that Organizational Justice and Perceived Organizational Support influen the Employee of Engagement Regional Secretariat of West Sumatra Province. Organizational Justice, Perceived Organizational Support and Employee Organizational Citizenship Behavior Regional Secretariat of West Sumatra Province.
\end{abstract}

Keywords: organizational justice, perceived organizational support, employee engagement, employee organizational citizenship

\section{Introduction}

Human resources (HR) is one of the most important factors that cannot even be separated from an organization. HR is also the key that determines organizational development. In essence, human resources in the form of humans who are employed in an organization as a driver to achieve the goals of the organization.

However, in an organization individual abilities sometimes do not mean if there is no extra-role behavior. Extra-role behavior is behavior in work that is not found in the formal work description of the employee but is highly valued if employees are shown because it increases the effectiveness and survival of the organization (Katz,1978). The behavior of extra-roles in organizations is also known as organizational citizenship behavior (OCB), and people who display OCB's behavior are called good citizens. Examples of behavior that includes the OCB group are helping colleagues, volunteering to do extra activities in the workplace, avoiding conflicts with coworkers, protecting the organization's property, respecting applicable regulations in the organization, tolerating less ideal / pleasant situations at work, giving advice information that builds up at work, and does not waste time at work (Robbins, 2015).

Organizational Citizenship Behavior (OCB) is a helpful attitude shown by organizational members, which is constructive in nature, valued by the company but not directly related to individual productivity (Steers, Porter, Bigley, 1996). According to Organ (2006), OCB is a form of behavior that is an individual choice and initiative, not related to the organization's formal reward system but in aggregate increases organizational effectiveness. This means that the behavior is not included in the job requirements or job descriptions so that if not shown, no punishment is given.

According to Organ (2006), OCB consists of five dimensions: (1) altruism, that is, behavior helps alleviate the work aimed at individuals in an organization, (2) courtesy, which is to help coworkers prevent problems related to their work by giving consultation and information and respect for their needs, (3) sportsmanship, namely tolerance to situations that are not ideal at work without complaining, (4) civic virtue, which is involved in organizational activities and cares about the 
survival of the organization, (5) conscientiousness, namely do things that benefit the organization such as obeying the rules in the organization.

Employee OCB behavior can be influenced by several factors, one of which is organizational justice as in the research conducted by Elsaid (2014: 9). The results of his research show that organizational justice along with its dimensions are capable of being predictors of OCB. Organizational justice is considered important, because based on the theory of justice, it is said that employees tend to compare the ratio between the effort or contribution they make, balanced with the results that have been received (Gibson et al., 2009). Li and Cropanzano (2009) state that organizational justice can improve individual performance, give birth to organizational citizenship behavior (OCB), good mental health, low stress levels, and a variety of good individual attitudes. In the previous research study found a positive and significant correlation between the three dimensions of organizational justice (distributive justice, procedural justice, and interactional justice) with OCB (Jafari and Bidarian, 2012), while Polat (2016) found that the three dimensions of organizational justice had a significant positive effect towards OCB (Polat, 2016). Another study by Ratnawati and Khairul Amri (2013) also found that organizational justice had a significant positive effect on OCB. Cahayu (2015) who stated that organizational justice has a significant positive influence on job satisfaction and organizational citizenship behavior.

In addition to organizational justice, organizational citizenship behavior also affects the level of OCB employees. According to Rich et al (2010), states that organizational citizenship behavior is influenced by perceived organizational support. Eisenberger et al (1986) in this case defines perceived organizational support as employees' global beliefs regarding the extent to which organizations care about their welfare and value their contributions. The global belief in question is the existence of consistency of employees regarding various assessments of the organization that might be given to them and various actions that can be taken by the organization both beneficial and detrimental to them. Along with Meliana's research (2018) which states that Perceived Organizational Support (POS) have an influence on organizational citizenship behavior (OCB). Ferry (2006) which states that there is a relationship between perceptions of the quality of superior-subordinate interactions and perceptions of organizational support together with employee Organizational Citizenship Behavior and there is no relationship between perceptions of organizational support with employee Organizational Citizenship Behavior. OCB does not only stand alone without the factors predicted to encourage the creation of OCB. In some previous studies employee engagement is one of the factors predicted to affect OCB (Ologbo \& Sofian, 2013). Employee engagement is intended as an awareness and willingness of employees to have involvement in terms of advancing their company so that employees feel bound by their work and organization. Whittington and Galpin (2010) in their study also suggested that employee engagement will generate OCB in both roles and extra-roles in an organization.

\section{Methods}

Based on the formulation of the problem and research objectives, the types of research used are Organizational Justice, Perceived Organizational Support and Employee Engagement, Organizational Citizenship Behavior. The study population was all employees of the Regional Secretariat of West Sumatra Province. Data collection uses questionnaires by giving or collecting questionnaires to respondents. This study uses survey techniques with 464 respondents. The analytical method used is the analysis of exogenous variable pathways and endogenous variables.

\section{Results and Discussion}

Path analysts are used to see the effect of exogenous variables on endogenous variables through other endogens (intervening variables) and measure the direct and indirect effects of one variable on other variables. The following is the result of the first substructure of analysis in this study: 
Table 1 Results of First Sub Structure Analysis

\begin{tabular}{lcccc}
\hline \multicolumn{1}{c}{ Variable } & Coefficient & t-value & Sig. & Result \\
\hline Organizational Justice $(\mathrm{X} 1)$ & 0,389 & 6,535 & 0,000 & Significant \\
\hline Perceived organizational support ( X2) & 0,311 & 5,220 & 0,000 & Significant \\
\hline
\end{tabular}

Source: Primary Data Processed (2019)

From the above calculation results, the coefficient of each independent variable along with t test results as follows:

a. The coefficient of Organizational Justice is 0,389 and t-value is 6,535 on sig. 0,000 which is smaller than alpha 0,05. this result shows there is effect of Organizational Justice to employee engagement.

b. The coefficient of Perceived organizational support is 0,311 and t-value is 5,220 on sig. 0,000 which is smaller than alpha 0,05. this result shows there is effect of Perceived organizational support to employee engagement.

The Calculations show that there is an influence of Organizational Justice and Perceived organizational support on employee engagement. Based on the above calculations, the analysis diagram can be shown as follows

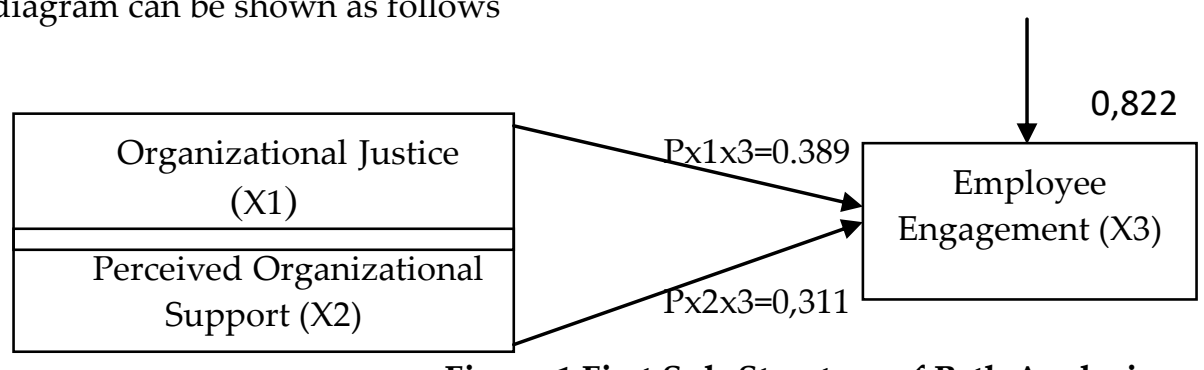

Figure 1 First Sub-Structure of Path Analysis

Based on the results of data analysis, that Organizational Justice and Perceived organizational support on employee engagement. Therefore, data analysis can proceed to the second sub-structure.

Analysis of the second structure to determine the effect of Organizational Justice (X1), Perceived Organizational Support (X2) and Employee Engagement on Organizational Citizenship Behavior (Y) Regional Secretariat of West Sumatra Province in the following table:

Table 2 Results of Second Sub Structure Analysis

\begin{tabular}{lcccl}
\hline \multicolumn{1}{c}{ Variable } & Coefficient & t-value & Sig. & Result \\
\hline Organizational Justice $(\mathrm{X} 1)$ & 0,223 & 3,322 & 0,001 & Significant \\
\hline Perceived organizational support $(\mathrm{X} 2)$ & 0,223 & 3,424 & 0,001 & Significant \\
\hline Employee Engagement $(\mathrm{X} 3)$ & 0,242 & 3,433 & 0,000 & Significant \\
\hline
\end{tabular}

Source: Primary Data Processed (2017)

From the above calculation results, the coefficients of each independent variable along with t test results as follows:

a. The coefficient of Organizational Justice is 0.223 and the t-value is 3,322 in sig. 0,001 which is smaller than alpha 0,05. This results shows there is effect of the Organizational Justice to Organizational Citizenship Behavior.

b. The coefficient of Perceived organizational support is 0.223 and the t-value is 3,424 in sig. 0.001 which is smaller than alpha 0.05 . This results shows there is effect of the Perceived organizational support to Organizational Citizenship Behavior.

c. The coefficient of Employee Engagement is 0.242 and the t-value is 3,433 in sig. 0.000 which is smaller than alpha 0.05. This results shows there is effect of the Employee Engagement to Organizational Citizenship Behavior

The calculations show that there is an influence of Organizational Justice on Organizational Citizenship Behavior, Perceived organizational support on Organizational Citizenship Behavior and 
Employee Engagement on Organizational Citizenship Behavior. Based on the above calculation, it can be shown the analysis diagram as follows:.

calculation, it can be shown the analysis diagram as follows:

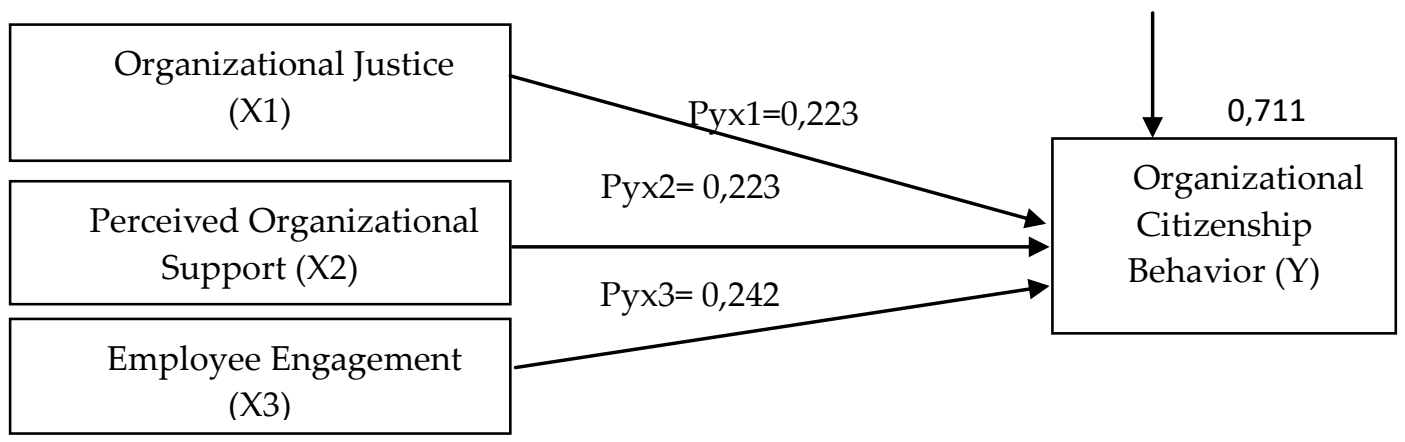

Figure 2 Second Sub-Structure of Path Analysis

Based on the results of data analysis is known that Organizational Justice Perceived Organizational Support and Employee Engagement affect Organizational Citizenship Behavior. Therefore, data analysis can be continued to the path diagram.

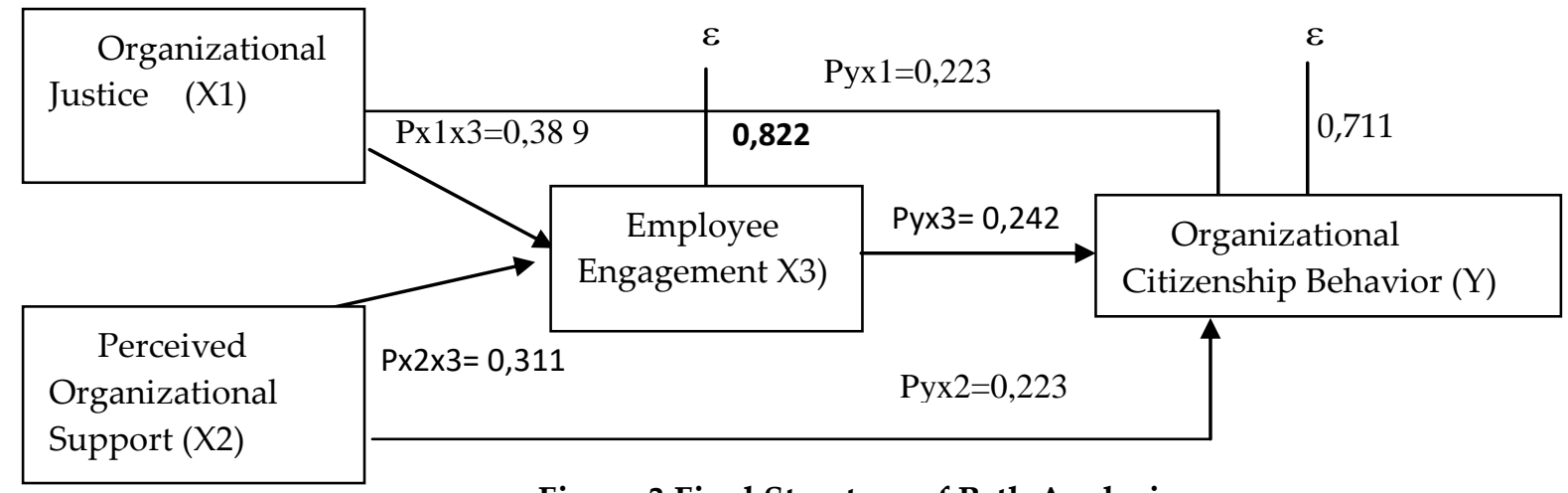

Figure 3 Final Structure of Path Analysis

\section{Hypothesis testing}

\section{Hypothesis 1}

From result of $\mathrm{t}$ test show value of path coefficient for Organizational Justice variable to Employee Engagement (Px3x1) is 0,389 with t-value for Organizational Justice variable 6,535 at significant value $0,000<0,05$ then Ho rejected Ha accepted, there is significant influence between Organizational Justice to Employee Engagement of the Regional Secretariat of West Sumatra Province.

\section{Hypothesis 2}

From result of $t$ test show value of path coefficient for Perceived Organizational Support variable to Employee Engagement $(\mathrm{P} \times 3 \times 2)$ is 0,311with t-value for Employee Engagement variable 5,220 at significant value $0,000<0,05$ so Ho is rejected, Ha accepted, there is significant influence between Perceived Organizational Support to Employee Engagement of the Regional Secretariat of West Sumatra Province.

\section{Hypothesis 3}

From result of $t$ test show value of path coefficient for Organizational Justice variable to Organizational Citizenship Behavior (Pyx1) is 0,223 with t-value for Organizational Justice variable 3,322 at significant value $0,001<0,05$ so Ho rejected Ha accepted, there is significant influence between 
Organizational Justice to Organizational Citizenship Behavior of the Regional Secretariat of West Sumatra Province.

Hypothesis 4

From result of $t$ test show value of path coefficient for Perceived Organizational Support variable to Organizational Citizenship Behavior ( $\mathrm{Pyx} 2$ ) is 0,223 with t-value for for Perceived Organizational Support variable 3,424 at significant value $0,001<0,05$ so Ho rejected Ha accepted, there is significant influence between Perceived Organizational Support to Organizational Citizenship Behavior of the Regional Secretariat of West Sumatra Province.

\section{Hypothesis 5}

From result of $t$ test show value of path coefficient for Employee Engagement variable to Organizational Citizenship Behavior (Рyх3) is 0,242 with t-value for Employee Engagement variable 3,433 at significant value $0,001<0,05$ so Ho rejected Ha accepted, meaning there is significant influence between Employee Engagement variable to Organizational Citizenship Behavior of Regional Secretariat of West Sumatra Province.

Effect of Organizational Justice on Employee Engagement of the Regional Secretariat of West Sumatra Province.

Based on the first hypothesis, organizational justice has a significant effect on employee engagement employees of the Regional Secretariat of West Sumatra Province. This shows that the importance of organizational justice to improve employee engagement. Employees will have high employee engagement if the Regional Secretariat of West Sumatra Province implements organizational justice properly.

The results of the study are in line with Meily \& Elisabeth (2012: 105) the influence of perceptions of fairness on various kinds of work outcomes is possible is the result of some employee engagement. When employees have a high perception of fairness in their organization, it is certain that they feel obliged or required to be fair in playing their role by giving more than the level of engagement. Low equity perceptions allow employees to withdraw and release themselves from their work roles. Justice is also one of the working conditions in the engagement model. Reduced justice can worsen burn out and while positive perceptions of justice can improve engagement (Maslach et al., 2001; in Saks, 2006: 606).

\section{Effect of Perceived Organizational Support on Employee Engagement of the Regional Secretariat of West Sumatra Province}

Based on the first hypothesis, perceived organizational support has a significant effect on employee engagement employees of the Regional Secretariat of West Sumatra Province. This shows that the importance of perceived organizational support to improve employee engagement. Employees will have high employee engagement if the West Sumatra Provincial Secretariat gives a perceived good organizational support.

The results of this study are in line with Maslach et al in Saks, (2006: 606) that low equity perceptions allow employees to withdraw and release themselves from their work roles. Justice is also one of the working conditions in the engagement model. Reduced justice can worsen burn out and while positive perceptions of justice can improve engagement.

Employee engagement will occur if there is support from the organization where they work. Rhoades \& Eisenberger (2002) found that Perceived Organizational Support has an impact on increasing organizational commitment, feelings towards work such as job satisfaction and positive mood, job involvement or employee work involvement, work performance, desire to be in the organization and reduce work tension, and reduce the level of withdrawal behavior so that it can increase organizational productivity.

According to Bakker and Demerouti (2007: 312), states that the factors that influence the emergence of engagement employees are Job Resources, which are work resources that cover various aspects, one of which is the presence of social support. Social support here refers to perceived 
organizational support The results of this study are in line with the research of Silvia (200) which states that there is a significant effect perceived organizational support has a significant effect on employee engagement. Ade (2015) stated that the influence of perceived organizational support partially on work engagement. Endah (2017) which states that the more positive perceptions of organizational support, the higher employee engagement.

\section{Effect of Organizational Justice on Organizational Citizenship Behavior of the Regional Secretariat of West Sumatra Province.}

Based on the third hypothesis, organizational justice has a significant effect on Individual Organizational Citizenship Behavior Provincial Secretariat employees West Sumatra. This shows that the importance of organizational justice is to improve individual Organizational Citizenship Behavior . Employees will have Individual Organizational Citizenship Behavior highif the West Sumatra Provincial Secretariat provides organizational justice well.

The results of this study are in line with Lawler cited by Handi and Fendy (2007: 102) stating that the distribution of corporate rewards such as salaries, promotions, job evaluations and work tenure has a strong influence on organizational citizenship behavior among employees. Folger and Konovsky (2002: 130) state that the perception of distributive justice as one type of organizational justice is significantly related to organizational citizenship behavior.

Polat (2016) and Fory (2014) that distributive justice has a positive and significant effect on OCB. These results indicate that the higher the employee's perception of justice received in giving rewards can foster higher employee behavior related to behaviors that benefit the organization as a whole, such as: conscientiousness, sportsmanship, and civic virtue. It's a big five theory, that behavior conscientiousness is a more careful attitude and listening to the heart, having good self-control, being organized, prioritizing tasks, following norms and regulations, and so on. An example of the behavior conscientiousness shown by employees is the level of acceptance and level of employee compliance with the rules and procedures that exist within the organization. Sportsmanship behavior can be seen from the level of tolerance and complaints (complaints) individuals in their work. Employees who have a high level of sportsmanship are very concerned about details in their work, fair behavior in carrying out work with a minimum level of complaints and followed by high adaptability to the situation and work environment. A behavior civic virtue person scan be demonstrated through full participation (self involvement) and more attention to the organization where he works. The high behavior civic virtue of employees is shown by the high attention of employees to the interests of the workplace organization by playing an active role in all activities within the organization, such as: employee training, workshops, committees and others as well as the level of attention employees have on important information can benefit the organization.

The results of this study are in line with the research of Ratnawati (2013) which states that organizational justice and trust in superiors have a significant effect on organizational citizenship behavior (OCB) on civil servants within the Iskandar Muda Military District in Banda Aceh. Akhmad (2016) which states that there is a positive and significant influence on organizational citizenship behavior. Veronika (2017) who states that distributive justice and interactional justice have a significant positive effect on OCB-I and OCB-O; procedural justice does not have a significant effect on OCB-I but procedural justice has a significant positive effect on OCB-O.

Effec of Perceived Organizational Support on Organizational Citizenship Behavior of the Regional Secretariat of West Sumatra Province.

Based on the fourth hypothesis, Perceived Organizational Support has a significant effect on Individual Organizational Citizenship Behavior employees of the Regional Secretariat of West Sumatra Province. This shows that the importance of Perceived Organizational Support to improve individual Organizational Citizenship Behavior. Employees will have Individual Organizational Citizenship Behavior high if the Regional Secretariat of West Sumatra Province provides Perceived Organizational Support well. 
The results of the study are in line with the Opinion opinion (2011: 80), saying that perceptions of organizational support perceived at a high level will increase organizational citizenship behavior. According to Bakker and Demerouti (2007: 312), states that the factors that influence the emergence of engagement employees are Job Resources, which are work resources that cover various aspects, one of which is the presence of social support. Social support here refers to perceived organizational support.

The influence of Perceived Organizational Support with Organizational Citizenship Behavior shows that employees in the Regional Secretariat of West Sumatra Province have a positive perception of company support they have received from the company so that employees feel they have the responsibility to reciprocate by doing the best work possible and volunteering to do work that exceeds their main duties. Because according to Noruzy et al (2011) states that the perception of positive organizational support causes employees to care about the welfare of the organization, increase organizational commitment, help organizations to achieve goals, reduce misunderstandings in work and make them become more loyal in the organization.

The level of support the organization present a direct connection employee perceptions with how employees are bound and involved in the work danpekerjaan-related behaviors such as citizenship behavior organization (Andrews \& Kacmar 2001: 347)

The results are consistent with research Lailiy (2017) which states that there is positive perceived organizational support for organizational citizenship behavior. Meliana (2018) which states that perceived organizational support (POS) has an influence on organizational citizenship behavior (OCB) through organizational trust as an intervening variable. Endah (2017) which states that the

Effect of Employee Engagement variable to Organizational Citizenship Behavior of Regional Secret ariat of West Sumatra Province

Based on the fifth hypothesis, employee engagement has a significant effect on Individual Organizational Citizenship Behavior employees of the Regional Secretariat of West Sumatra Province. This shows that the importance of employee engagement to improve individual Organizational Citizenship Behavior . Employees will have Individual Organizational Citizenship Behavior high if the West Sumatra Provincial Secretariat provides good employee engagement.

The research results are in line with the opinion of Bakker and Demerouti (2007: 215-217) revealing that the organizational impact of employee engagement is related to positive work relations attitudes, individual health, extra role behavior and performance. In addition, workers will feel more satisfied with their jobs, feel more committed to the organization, and do not intend to leave the organization or seek alternative employment elsewhere, with employee morale, high dedication and solubility in work, will create extra role behavior which or employee performance is extra role also called Organizational Citizenship Behavior (OCB) which will be able to make the organization more effective.

According to Wirawan (2013) the factors that influence OCB include personality, organizational culture, organizational climate, job satisfaction, organizational commitment, transformational leadership \& servant leadership, employee social responsibility, employee age, employee engagement, collectivism and organizational justice.

The results of this study are in line with Meydy's (2015) study which states that Employee Engagement has a positive effect on Organizational Citizenship Behavior. Jenetha (200) stated that Employee Engagement has a positive and significant effect on Organizational Citizenship Behavior.

\section{Conclusions}

Based on the results of the research and discussion, the conclusion is Justice of the organization has a significant influence on employee engagement employees of the Regional Secretariat of West Sumatra Province. This means that the higher organizational justice, employee engagement will increase.Perceived Organizational Support has a significant influence on employee engagement employees of the Regional Secretariat of West Sumatra Province. This means that the higher the Perceived Organizational Support, the employee engagement will increase. 
Organizational justice has a significant influence on individual organizational citizenship behavior employees of the Regional Secretariat of West Sumatra Province. This means that the higher organizational justice, the individual Organizational Citizenship Behavior will increase.Perceived Organizational Support has a significant influence on Individual Organizational Citizenship Behavior employees of the Regional Secretariat of West Sumatra Province. This means that the higher the Perceived Organizational Support, then the Organizational Citizenship Behavior Individual employees will increase.Employee engagement has a significant effect on Individual Organizational Citizenship Behavior employees of the Regional Secretariat of West Sumatra Province. This means that the higher employee engagement employee's, the Organizational Citizenship Behavior will increase.

\section{References}

Ade Indah Dwitasari. (2015). Effect of Perceived Organizational Support and Organizational-Based Self Esteem To Work Engagement. Journal of Mediapsi. Volume 1 Number 1, Page 40-50

Akhmad Sanhaji. (2016). Effect of Organizational Justice and Organizational Culture on Organizational Citizenship Behavior through Organizational Commitment and Job Satisfaction. Journal of Education: Theory, Research and Development. volume: 1 Number: 5. Pages: 917-926

Arikunto, Suharsimi. (2010). Research Procedures, A Practice Approach. Jakarta: Rineka Cipta

Bakker, AB, \& Demerouti, E. 2007. The Demands-Resources Job Model: State of The Art. Journal of Managerial Psychology, Vol 22, No 3 pp 309-328 Cropanzano. 2007. The Management of Organizational Justice. Academy of Management Perspectives. 34-48.

Eisenberger. R., Huntington. R., Hutchison. S., \& Sowa. D ,. 1986. "Perceived Organizational Support". Journal Applied Psychology. Vol. 71. No. 3,500-50

Endah Mujiasih. (2015). Relationship between Perception Support Organizations (Perceived Organizational Support) With Employee Engagement (EmployeeEngagement). UndipPsychology Journal Vol. 14 No.1 April 2015, 40 - 51

Folger, R., \& Konovsky. (2002). Effect of Procedural Justice and Distributive Justice on Reactions to Pay Raise Decicions, Academy of Management Journal, 32 (1): 130Menstruation, M. and Sims, J. 2009. Employee Engagement: Maximizing Organizational Performance. Philadelphia: Right Mangement Inc.

Lailiy Anisatul Maula. (2017). Perceived Organizational Support and Its Effects on Organizational Citizenship Behavior with Job Satisfaction as Intervening Variables (Study on East Java Park Employees 1). Journal of Business Administration (JAB) I Vol. 50 No. 4

Li, Andrew and Russell Cropanzano. (2009). Do East Asians Respond More / Less Strongly to Organizational Justice Than North Americans? A Meta-Analysis. Journal of Management Studies,46 (5): 787-805.

Jafari, Parivash and Shabnam Bidarian. (2012). The Relationship Between Organizational Justice andOrgational Citizenship Behavior. Procedia, Social and Behavior Sciences,

Jenetha Kartika, (2015). Analystsare the Factors Affecting Organizational Citizenship Behavior in BPR Employees in Batam. Management Journal, Vol. 14, No.2, May 2015

Katz, D., and Kahn, RL (1978). The Social Psychology of Organization, 2nd ed., New York: Wiley \& Sons.

Meliana Sutanto. (2018). Effects of Perceived Organizational Support (POS) on Organizational Citizenship Behavior (OCB) with Organizational Trust As theVariableMost Involvedat Hypermart Royal Plaza Surabaya. Agora Vol. 6, No. 1, (2018).

Meliana Sutanto. (2018). Effects of Perceived Organizational Support (POS) on Organizational Citizenship Behavior (OCB) with Organizational Trust As Intervening Variables at Hypermart Royal Plaza Surabaya. Agora Vol. 6, No. 1, (2018)

Ologbo, AC, \& Sofian, S. (2013). Individual and Organizational Factors of Employee Engagement on Employee Work Outcomes, Procedia - Social and Behavioral Sciences.3 (3), 1-9 
Organ, DW, Philip M, P., dkk. (2006). Organizational Citizenship Behavior: Its Nature, Antecendent, And Consequense. California: Sage Publications, Inc.

Polat, Soner. (2016). The Relationship Between Organizational Justice Perceptions, Level of School and Trust Administrators, and Organizational Citizenship Behavior of Secondary School Teacher Turkey; downloaded from http://files.eric.ed.gov/fulltext/ED507710.pdf)

Ratnawati, (2013). Effects of Organizational Justice, Trust in Bosses on Organizational Citizenship Behavior. Ekono Journal ofManagement and Business. Volume 1 Number June 1, 2013, Pages 56-73

Rich BL, Jeffrey AL, Eean RC, (2010), Ob Obstruction: Antecedents And Effects On Job Performance, Academy of Management Journal 2010, Vol. 53, No. 3, 617-635

Robbins, Stephen P., TA Judge. (2015). Organizational Behavior 16. Edition: Jakarta: Four Salemba

Rhoades, L., \& Eisnverger, R. (2002). Perceived Organizational Support. in the National Forum of the Applied Educationl Research Journal. 13 (3), 1-13

Saks, AM (2006). Antecedents and Consequences of Employee Engagement. Journal of Managerial Psychology, 21, pp600-619.

Silvia Indra Mustika. (2017). Effects of Perceived Organizational Support on Employee Engagement and Organizational Citizenship Behavior (Study on Medical Staff atHospital Lavalette Malang). Journal of Business Administration (JAB) | Vol. 47 No.1 June 2017 matters 9-15

Connect, Roby, Thoyib, Armanu. Afnan, Eka. and Surachman. (2011). Effect of Job Satisfaction, Organizational Commitment, Personality and Professionalism on lecturers Organizational Citizenship Behavior and its impact on Lecturer Performance, study at Palangka Raya University, Journal of Management Applications, Vol 10 Number 1 March 2012, ISSN 16935241.

Steers, RM, \& Porter, LW (1996). Motivation and Work Behavior. 3rd edition. New York: McGraw Hill Book Company.

Veronika Agustini Srimulyani. (2017). Organizational Justice and Its Consequences Against theOrgational Citizenship Behavior of High School and Vocational School Teachers in Madiun City. Indonesian Management Journal. Vol 17 No.2

Whittington, JL, \& Galpin, TJ (2010). The engagement factor: building a high commitment organization in a low-commitment world. Journal of Business, 31(5), 14-24 